Print ISSN: 2288-4637 / Online ISSN 2288-4645

doi:10.13106/jafeb.2020.vol7.no10.1119

\title{
What Determines Interest in Becoming a Student of Professional Accounting?*
}

\author{
I Ketut YADNYANA ${ }^{1}$, Ni Luh Putu Trisna DEWI ${ }^{2}$
}

Received: August 01, 2020 Revised: September 06, 2020 Accepted: September 11, 2020

\begin{abstract}
This study aims to identify the determinants of student interest in pursuing Accounting Professional Education (Indonesia: PPAk) in Province of Bali. The determinants which the author has used are: independent variables are social motivation, career motivation, quality motivation, and duration of education. The sample in this study comprises of 75 respondents who are students of Accounting discipline at the Faculty of Economics and Business at universities in the Province of Bali. Data was collected using a questionnaire and have been processed using multiple regression analysis. The results show that social motivation, career motivation, and quality motivation have a positive effect on students' interest in studying Accounting Professional Education. On the other hand, the duration of the accounting course has a negative effect on students' interest in studying this program. The importance of role of a professional accountant in realizing transparency in public life, and an economy that is free from financial deceit and fraud makes the role of professional accounting institutions very important. However, graduates' who desire to continue their studies in the PPAk program tends to be low. The findings of this research are expected to become the basis for policy makers in formulating rules related to the development of the accounting profession in the society, especially in Indonesia.
\end{abstract}

Keywords: Motivation, Education Duration, Study Interest, Accounting Professional Education, Indonesia

JEL Classification Code: I23, J24, J44, M40, M49

\section{Introduction}

Previous research stated that the determinants that influence a student's decision to choose a university in Vietnam are prestige, geographical location, facilities, attractiveness of the field and media (Le, 2020). Others have revealed that the factors that determine students' decisions about courses of study such as accounting and other subjects at business schools depends on the

\footnotetext{
*Acknowledgements:

The authors thank Adrian B. Coen as the Proofreader.

${ }^{1}$ First Author and Corresponding Author. Professor, Department of Accounting, Faculty of Economics and Business, Universitas Udayana, Indonesia [Postal address: Jalan PB Sudirman, Denpasar, Bali, 80232, Indonesia] Email: ketutyadnyana@unud.ac.id ${ }^{2}$ Department of Accounting, Faculty of Economics and Business, Universitas Udayana, Indonesia. Email: dewitrisna56@gmail.com

(c) Copyright: The Author(s)

This is an Open Access article distributed under the terms of the Creative Commons Attribution Non-Commercial License (https://creativecommons.org/licenses/by-nc/4.0/) which permits Non-Commercial License (https://creativecommons.org/licenses/by-nc/4.0/) which permits
unrestricted non-commercial use, distribution, and reproduction in any medium, provided the original work is properly cited.
}

confidence of students in their academic strength as well as their abilities to manage the academic work (Owusu, Bekoe, Okyere, \& Welbeck, 2019) and also their gender (Hauff \& Nilsson, 2020). Previous research has also found that students' awareness of continuing professional education was marked by spontaneity and gratuity (Shatskaya, 2019). The role of parental support, teacher support, and career decision-making self-efficacy as sources of career optimism (Garcia, Restubog, Bordia, Bordia \& Roxas, 2015) is also believed to influence students' decisions to continue their studies. This paper examines what determines interest on the part of accounting graduates in attending an Accounting Professional Education (in Indonesia: PPAk) program. The purpose of the PPAk is to produce graduates who have expertise and competence in professional accounting. PPAk plays a vital role in preparing graduates to become professional accountants, for example, as Certified Public Accountants (CPA). Public accountants are an important element in realizing transparency in society, and an economy to make it free from deceit and fraud that is financial in nature (Arifianto \& Sukanti, 2014). 
The facts show that, currently, only a small number of accounting graduates are interested in studying the PPAk programs. According to www.kompas.com on March 21, 2016, the number of accountants in Indonesia is still minimal compared to other South East Asian countries (Table 1). In terms of the number of professional accountants, Indonesia ranks fourth. However, when viewed in terms of the percentage of the population who are public accountants, Indonesia ranked at a low seventh position. When compared to Thailand, Malaysia and Singapore, Indonesia has a bigger potential for having good number of accountants because this can be supported a large Indonesian population. This shows that the interest of Indonesian people, especially accounting graduates, in becoming a public accountant is still low. The low growth in the number of public accountants in Indonesia could be caused by various factors that reduce the motivation of accounting graduates to enter the public accounting profession as their career choice. There are many factors that influence students' interest in joining Accounting Professional Education programs such as career motivation, economic motivation, quality motivation, degree motivation, social motivation, education costs, duration of education, and motivation to take the public accountant certification examination.

Previous studies have examined the influence of motivation in studying PPAk (Vesperalis \& Muliartha, 2017). Motivation is a condition of an individual that drives his or her desire to carry out certain activities in order to achieve their goals (Dewi \& Setiawanta, 2014; Robbins, 2008). To encourage students' interest in studying PPAk, social motivation, career motivation, and quality motivation are needed, apart from theses, the interest of students is also influenced by how long they have been in education.
Social motivation is a type of motivation is a type of activity in which a person engages to which others have an opinion/approval about and the person also considers the consequences for others for his activity. (Martameh, 2012). Social motivation can also be said to be an encouragement from within a person to carry out an act that has social value and to get recognition and appreciation from those in one's environment. Social motivation can cause individuals to behave differently because it is related to the economic motivation that underpins it (Akerlof, 2006). Previous studies have shown that social motivation has a positive effect on student interest in participating in PPAk (Nurhayani, 2012).

Career motivation is something that originates within a person that leads them in making an effort that can improve performance and have an impact in terms of reaching a higher level on the career ladder. Career motivation is a condition that makes a person move toward his or her goals and is related to the work environment (Lunenburg, 2015; Paais \& Pattiruhu, 2020; Pancasila, Haryono, \& Sulistyo, 2020). Students who choose careers in public accountancy want job security, job satisfaction, they want accounting skills and a high potential income in the future (Zyl \& Villiers, 2011). PPAk is an educational program at a university that can influence the career development of accountants. PPAk also helps students who want to develop their expertise and abilities in accounting. Having a high career-oriented motivation for the future can increase students' and professionals' interest in participating in PPAk. Previous studies show that career motivation has a positive effect on students' interest in joining PPAk (Andoko \& Sukhemi, 2015; Berlinasari \& Erawati, 2017). (See Table 1 below)

Table 1: Number of Accountants in Listed ASEAN Countries

\begin{tabular}{|l|l|c|c|c|}
\hline No & \multicolumn{1}{|c|}{ Country } & $\begin{array}{c}\text { Number of Professional Accountants } \\
\text { as of January 2015 }\end{array}$ & $\begin{array}{c}\text { Population } \\
(\mathbf{1 , 0 0 0 s})\end{array}$ & Percentage \\
\hline 1 & Thailand & 62,739 & $68,251.00$ & 0.09192 \\
\hline 2 & Malaysia & 31,185 & $29,948.00$ & 0.10413 \\
\hline 3 & Singapore & 28,891 & $5,399.20$ & 0.53510 \\
\hline 4 & Indonesia & 24,587 & $248,818.10$ & 0.00988 \\
\hline 5 & Philippines & 18,214 & $99,384.50$ & 0.01833 \\
\hline 6 & Vietnam & 9,800 & $89,708.90$ & 0.01092 \\
\hline 7 & Myanmar & 1,948 & $61,568.00$ & 0.00316 \\
\hline 8 & Cambodia & 291 & $14,962.60$ & 0.00194 \\
\hline 9 & Laos & 176 & $6,644.00$ & 0.00265 \\
\hline 10 & Brunei & 56 & 406.2 & 0.01379 \\
\hline Total & & 187,517 & $625,090.50$ & 0.03000 \\
\hline
\end{tabular}

Source: Institute of Indonesia Chartered Accountants, 2015 
Quality motivation is the drive within a person to be able to obtain and improve their own quality and be able to carry out tasks properly and correctly according to their fields (Berlinasari \& Erawati, 2017). When good quality motivation is felt by someone and is supported by structured autonomy and emotional involvement, it will create an enabling environment that meets their basic needs, namely competence and knowledge (Vansteenkiste, Sierens, Soenens, Luyckx, \& Lens, 2009). PPAk can improve the quality of an accounting graduate (Kusumastuti \& Waluyo, 2013). Previous studies show that quality motivation has a positive effect on students' interest in participating in PPAk (Aryani \& Erawati, 2016; Dyastari \& Yadnyana, 2016).

Duration of education refers to a process whereby individuals organize and interpret their sensory impressions of the scheduled period of study that they have to undertake in accordance with the time span that is required. Most graduates of economics choose to work immediately after graduating because of economic needs or career pressure. Therefore the duration of study for the undergraduate accounting course (four years), plus the time to attend PPAk for ( 1 to 1.5 years) before finally landing a job or engaging in a related financially rewarding work may be considered to be too long for many students and may affect their decision to go through the accounting course.

Ultimately, this issue makes many graduates choose to work first instead of studying PPAk. Problems regarding the duration of education, and whether or not it is considered to be too long, rely on the perceptions of students and are relatively dependent on their individual assessment. This is in accordance with previous research which states that students who major in accounting are driven more by selfinterest (Owusu et al., 2019).

\section{Literature Review and Hypothesis Development}

\subsection{Maslow's Theory of Needs Hierarchy}

Abraham Maslow (1954) put forward a theory about motivation called the Theory of Hierarchy of Needs (Robbins, 2008). This theory explains that each individual has a variety of needs that can affect their behavior. This theory also states that, if someone decides to receive enough money for a job from an organization where he works, then the money does not exert an intense power anymore. A need will stop being the main motivation if the individual's needs reach their peak. Maslow's theory of motivation provides an explanation of the motivations that underlie a person to act on a different level from that of a person's needs. Maslow's theory can be used as a basis for determining the factors that motivate students to take part in PPAk.

Motivation is a psychological stage that raises and directs individual behavior to achieve a goal or goal-directed behavior. According to Schiffman and Kanuk (2009), motivation is explained as a driving force in a person that moves them to take up an action or indulge in a structured activity. Motivation arises from within an individual because of the needs they feel. Based on the definitions and theories, it can be concluded that motivation is an impetus caused by desire and individual needs directed at the goal of obtaining satisfaction from what is done.

\subsection{Social Motivation}

Social motivation is defined as an impetus for someone to engage in an act with socially valued goals and obtain recognition and appreciation from the environment in which they are located. By having an accountant's degree, an inner satisfaction arises where the person can be recognized for their abilities by other people or their environment. The importance of status as a social motivation will greatly affect the level of anxiety experienced by a person, besides which, social motivation is, psychologically speaking, capable of ignoring the role of one's gender (Buss, 1997). The desire for social relations with others plays a very central role in terms of the need to connect with others in addition to other aspects such as competence and the need for achievement (Ryan \& Powelson, 1991). Social motivational variables have a positive effect on accounting students' interest in studying PPAk (McClintock, 1972; Nurhayani, 2012).

H1: Social motivation has a positive effect on students' interest in studying PPAk.

\subsection{Career Motivation}

According to Benny and Yuskar (2006) a career is one's expertise or professionalism of in their field of knowledge which is assessed based on work experience that contributes to the organization. Careers can be termed as a series of promotions to get jobs that have a higher responsibility or a better placement with the aim a satisfying and financially rewarding work life (Kermis \& Kermis, 2010). Career selection is a form of self-expression because the choice shows one's motivation, knowledge, personality, and all the abilities that are possessed. Career motivation as a multidimensional factor which consists of three main elements, namely career endurance, career insight and career identity (Alnıaçık, Alnıaçık, Akçin, \& Erat, 2012). 
Previous research also shows that career motivation has a positive effect on student interest in participating in PPAk (Setyaningsih, 2016).

H2: Career motivation has a positive effect on students' interest in studying PPAk.

\subsection{Quality Motivation}

Quality motivation is an impetus that arises within people who have and improve their quality and ability in the area they are in charge of so that they can carry out their duties properly and correctly. The motivation of high quality develops the potential that exists in them, so that human resources improve in accordance with the quality they have. Quality is a dynamic condition related to products, services, human resources, processes, and the environment that meets or exceeds expectations (Goetsch \& Davis, 2002). Quality is the totality of the forms and characteristics of goods or services that demonstrate their ability to satisfy needs that are apparent or hidden (Heizer \& Render, 2004). Quality is a term that has a variety of interpretations depending on the views of stakeholders (Schindler, Puls-Elvidge, Welzant, \& Crawford, 2015). Quality motivation has a positive effect on students' interest in participating in PPAk (Condrorini, 2015). That research contradicts research showing that quality motivation does not significantly influence the interest of accounting students in studying PPAk (Widyastuti, Suryaningsum, \& Juliana, 2004). Based on the description above regarding quality motivation, the following hypotheses can be proposed:

H3: Quality motivation has a positive effect on students' interest in studying PPAk.

\subsection{Duration of Education}

Duration of education refers to a process whereby individuals organize and interpret their sensory impressions of the scheduled period of study that they had to undertake in accordance with the time span that is required to complete it. Duration of education is a process that must be undertaken by a student who is engaged in accounting education in order to obtain a professional degree as an accountant. Most graduates of economics choose to work immediately after graduating because of economic or career pressure. They seriously consider the period of study for undergraduate accounting (four years), plus the time to attend PPAk for
(1 to 1.5 years) before finally commencing work, to be too long. This issue makes many graduates choose to work first instead of studying PPAk. Problems regarding the duration of education, and whether or not it is considered to be too long, rely on the perceptions of students and are relatively dependent on their individual assessment. Faster the completion of the study, more interested students will be in taking PPAk. This statement is supported by research conducted by Setyaningsih (2016) which shows that the longer duration of education (study process) does not have a positive effect on students' interest in participating in PPAk. Other similar research conducted by Hadiprasetyo (2014) shows that perceptions of the study period have a positive and significant effect on the interest of accounting students in studying PPAk.

H4: The duration of education has a negative effect on the interest of accounting students in studying PPAk.

\section{Research Methods and Materials}

The independent variables used in this study are social motivation, career motivation, quality motivation, and duration of education. The dependent variable in this study is the interest of students in studying PPAk. This study uses measures from (Nurhayani, 2012) research to measure social motivation. Social motivation is measured using the following indicators: 1) desire to be superior to others; 2) the desire to get along well with others; 3 ) enjoy working with others; 4) the desire to earn prestige in the eyes of others; 5) desire to have an influence on others. To measure career motivation, this study uses a questionnaire from Kusumastuti and Waluyo (2013).

Career motivation is measured using the following indicators: 1) having work that is suited to one's educational background; 2) having opportunities for promotion; 3) improving one's ability to complete the workload; 4) achievements in one's work; 5) having professionalism and feeling pride in the accounting profession; 6) having a sense of responsibility regarding work; and 7) having access at a network in the world of work.

Quality motivation is measured using Kusumastuti and Waluyo (2013) questionnaire. Quality motivation is measured by the following indicators: 1) knowledge and expertise in the fields of taxation, auditing, finance, and management accounting; 2) knowledge of the latest developments in accounting policy and regulation issues; 3 ) understanding of the business environment; 4) interpersonal skills such as the ability to work in groups; 5) ability to solve 
problems; and 6) the ability to communicate well orally or in writing.

Finally, the duration of education is the length of time a person needs to complete his or her education. Indicators for length of education are as follows: 1) the maximum time limit for studying PPAk; 2) the length of the PPAk study period; and 3) the level of difficulty in graduating from PPAk (Linasari \& Fitriany, 2008). While the last variable is calculated using data on PPAk, the other variables are measured using a questionnaire. The authors use a 4-point Likert scale, with number 1 indicating strongly disagree and number 4 indicating strongly agree. This questionnaire was given to final year accounting students at the Faculty of Economics and Business of a university in the Province of Bali. Questionnaires that could be analyzed were obtained from 75 people. Table 2 shows the characteristics of the respondents in this study.

The technique of analysis used in this study is multiple regression, with the following model:

Int $=\alpha+\beta_{1}$ Soc $+\beta_{2}$ Car $+\beta_{3} Q u a+\beta_{4} D u r+\varepsilon$

Notes:

Soc : Social motivation

Car : Career motivation

Qua : Quality motivation

Dur : Duration of education

Int : Student interest in studying PPAk

Table 2: Characteristics of Respondents

\begin{tabular}{|l|c|c|}
\hline \multirow{2}{*}{$\begin{array}{l}\text { Characteristics of } \\
\text { Respondents }\end{array}$} & \multicolumn{2}{|c|}{ Amounts } \\
\cline { 2 - 3 } & Persons & Percentage \\
\hline Gender: & & \\
\hline Women & 56 & $75.3 \%$ \\
\hline Men & 19 & $24.7 \%$ \\
\hline Total & 75 & $100 \%$ \\
\hline
\end{tabular}

\section{Results and Discussion}

\subsection{Descriptive Statistics}

The results of the descriptive statistical analysis of this study are shown in Table 3 . The social motivation variable has a mean value of 3.21. This mean value is approaching the maximum value. This means that the answers to the statements contained in the social motivation questionnaire indicate that students' interest in participating in PPAk tends to be high. The standard deviation of social motivation is 0.470 . This value is lower than the mean value. This shows that the distribution of data, in the form of respondents' answers to the items in the statement of learning behavior, can be declared to be evenly distributed or the range of data, from one item to another, is not high.

The career motivation variable has a mean value of 3.27. This mean value is approaching the maximum value. This means that the answers to the statements contained in the career motivation questionnaire indicate that student interest in participating in PPAk tends to be high. The standard deviation of career motivation is 0.425 . This value is lower than the mean value. This shows that the distribution of data, in the form of respondents' answers to the items in the statement of learning behavior, can be declared evenly distributed or the range of data, from one item to another, is not high (see Table 3).

The quality motivation variable has a mean value of 3.26. This mean value is approaching the maximum value. This means that the answers to the statements contained in the quality motivation questionnaire indicate that students' interest in participating in PPAk tends to be high. The standard deviation of quality motivation is 0.441 . This value is lower than the mean value. This shows that the distribution of data, in the form of respondents' answers to the items in the statement of learning behavior, can be declared evenly distributed or the range of data, from one item to another, is not high.

Table 3: Results of Descriptive Statistical Analysis

\begin{tabular}{|l|c|c|c|c|c|}
\hline Variable & N & Minimum & Maximum & Mean & Std. Deviation \\
\hline Social motivation (X1) & 75 & 2.00 & 4.00 & 3.21 & 0.470 \\
\hline Career motivation (X2) & 75 & 2.33 & 4.00 & 3.27 & 0.425 \\
\hline Quality motivation (X3) & 75 & 2.50 & 4.00 & 3.26 & 0.441 \\
\hline Duration of Education (X4) & 75 & 2.00 & 4.00 & 3.01 & 0.580 \\
\hline Interest in Studying PPAk (Y) & 75 & 2.20 & 4.00 & 3.32 & 0.483 \\
\hline
\end{tabular}


The duration of education variable has a mean of 3.01. This mean value is approaching the maximum value. This means that the answers to the statements contained in the old education questionnaire indicate that student interest in participating in PPAk tends to be high. The standard deviation of the duration of education is 0.580 . This value is lower than the mean value. This shows that the distribution of data, in the form of respondents' answers to the items in the statement of learning behavior, can be declared evenly distributed or the range of data, from one item to another, is not high.

The variable of student interest in participating in the PPAk has a mean value of 3.32. This mean value is approaching the maximum value. This means that the answers to the statements contained in the questionnaire students' interest in participating in PPAk indicates that students' interest in participating in PPAk tends to be high. The standard deviation of career motivation is 0.483 . This value is lower than the mean value. This shows that the distribution of data, in the form of respondents' answers to the items in the statement of learning behavior, can be declared evenly distributed or the range of data, from one item to another, is not high.

\subsection{Results of Hypothesis Testing}

The results of the multiple regression testing displayed in Table 4 show that all independent variables have indicated significant results. The first hypothesis $\left(\mathrm{H}_{1}\right)$ states that the social motivational variable has a positive effect on student interest in participating in PPAk. According to the results of calculations in Table 4, it is known that the significance level of social motivation, which is 0.004 , is smaller than a $=0.05$, then $\mathrm{H}_{1}$ is accepted and $\mathrm{H}_{0}$ is rejected. These results indicate that social motivation has a positive influence on accounting students' interest in participating in the PPAk program. This research is in line with Maslow's hierarchy of needs theory, namely social needs, the need for love and satisfaction in establishing relationships with others, the need for satisfaction and a feeling of belonging and being accepted in a group, and the need for prestige, namely the need for status and position, self-respect, reputation and achievement. The influence of social motivation on interest in participating in PPAk is related to a person's need to attain self-satisfaction in terms of working together and dealing with others as well as getting awards and recognition from the surrounding environment related to the achievements that have been made. The results of this study are consistent with the previous results (McClintock, 1972; Nurhayani, 2012). According to the theory and the results of previous studies, it can be concluded that the stronger the social motivation of students in establishing relationships with others or with the environment, the higher the interest of students in participating in PPAk (see Table 4).

The results of the testing the second hypothesis $\left(\mathrm{H}_{2}\right)$ show that the career motivation variable has a positive effect on students' interest in participating in PPAk. According to the results of calculations in Table 4, it is known that the level of significance of career motivation, which is 0.002 , is smaller than $\mathrm{a}=0.05$, so $\mathrm{H}_{1}$ is accepted and $\mathrm{H}_{0}$ is rejected. These results indicate that there is a positive influence on career motivation possessed by accounting students in terms of their interest in participating in PPAk programs. This research is supported by the theory of needs proposed by McCleland (1961) which shows that every individual is motivated by various needs, one of which is the need for power that is closely related to the need to reach a leadership position (Robbins, 2008). The desire to have a better career can motivate someone to improve skills and improve quality in themselves and so encourage their interest in pursuing higher education that can support their career. The next step students must take after successfully completing university is to determine what their career will be. An educational institution has a great influence on the career development of an accountant. Most accounting students consider PPAk as an educational tool that makes a positive contribution to improving skills and securing a better career in the future. The results of this study are consistent with previous research which also showed that career motivation had a positive effect on student interest in participating in PPAk (Setyaningsih, 2016). This means that the higher the career motivation of a person, the more students will be interested in participating in PPAk.

Table 4: Results of Multiple Linear Regression Analysis

\begin{tabular}{|l|c|c|c|c|c|}
\hline Variable & \multicolumn{2}{|c|}{ Unstandardized coefficients } & \multirow{2}{*}{$\begin{array}{c}\text { Standardized } \\
\text { coefficients Beta }\end{array}$} & $\mathbf{t}$ & Sig. \\
\cline { 1 - 2 } & $\mathbf{B}$ & Std. Error & & \\
\hline (Constant) & 0.787 & 0.383 & & 2.052 & 0.044 \\
\hline Social Motivation $\left(\mathrm{X}_{1}\right)$ & 0.277 & 0.093 & 0.27 & 2.999 & 0.004 \\
\hline Career Motivation $\left(\mathrm{X}_{2}\right)$ & 0.367 & 0.113 & 0.323 & 3.232 & 0.002 \\
\hline Quality Motivation $\left(\mathrm{X}_{3}\right)$ & 0.276 & 0.099 & 0.253 & 2.778 & 0.007 \\
\hline Duration of Education $\left(\mathrm{X}_{4}\right)$ & -0.123 & 0.056 & -0.184 & -2.742 & 0.008 \\
\hline
\end{tabular}


The results of the testing of the third hypothesis $\left(\mathrm{H}_{3}\right)$ indicate that the quality motivation variable has a positive effect on student interest in participating in PPAk. According to the results of calculations in Table 4, it is known that the significance level of social motivation, which is 0.007 , is smaller than $\mathrm{a}=0.05$, so $\mathrm{H}_{1}$ is accepted and $\mathrm{H}_{0}$ is rejected. These results indicate that there is a positive perception of quality motivation that the accounting students possess in terms of their interest in participating in a PPAk program. This research is supported by McCleland's needs theory which shows that each individual is motivated by various needs, one of which is the need for achievement, namely the drive for achievement related to a set of standards and the striving to succeed (Robbins, 2008). The quality of one's education is certainly strongly influenced by the level of education that one has reached. The quality of personal expertise possessed by someone, especially in the accounting profession, is of considerable concern, especially in the world of work because it will directly affect the resulting performance. The results of this study are consistent with research that show that quality motivation has a positive effect on student interest in participating in PPAk (Condrorini, 2015). This means that the higher the quality motivation that an accounting student has, the higher their interest in studying PPAk.

The results of the testing of the fourth hypothesis $\left(\mathrm{H}_{4}\right)$ show that the variable duration of education has a negative effect on students' interest in participating PPAk. According to the results of calculations in Table 4, it is known that the level of significance of the duration of education, which is 0.008 , is smaller than $a=0.05$, and so $\mathrm{H}_{4}$ is accepted and $\mathrm{H}_{0}$ is rejected. These results indicate that there is a negative perception regarding the duration of education on the part of accounting students in terms of their interest in participating in a PPAk program. Duration of education is a process that must be undertaken by a student engaged in accounting education in order to obtain a professional degree as an accountant. Most graduates of economics choose to work immediately after graduating because of economic or career pressure. They feel that the period spent at the university as undergraduate studying accounting for four years, plus the time needed to attend PPAk (1 to 1.5 years) before finally commencing work, is too long. Ultimately, this issue results in many graduates choosing to work first instead of studying with PPAk. Problems regarding the duration of education, and whether it is too long, rely on the perceptions of students and are relatively dependent on their individual assessment. If the study process could be completed more quickly, the students would be more interested in participating in PPAk. This means that the longer the duration of the education undertaken, the lower the interest of students in studying PPAk.

\section{Conclusions}

The importance of the role of professional accountants in realizing transparency in public life, and an economy that is free from deceit and fraud that is financial in nature makes the role of professional accounting institutions very important. However, the facts show that interest in studies at these institutions tends to be low. This paper has examined the factors that influence the interest of accounting graduates in attending programs on accounting professional education (PPAk). The findings of this study show that determinants of interest in studying PPAk consist of social motivation, career motivation, quality motivation, and duration of education. Social motivation, career motivation, and quality motivation are shown to have a positive influence on study interest in PPAk. Conversely, duration of education has a negative effect on interest in studying PPAk.

This study has only been conducted at local educational institution so it is expected that further research would broaden the scope of research. The results of this research are expected to be the basis for policy makers in formulating rules related to the development of the accounting profession in society. In addition, further research could compare interest in studying PPAk in various regions and even compare countries. This needs to be carried out to determine the prospects for the development of the accounting profession, especially in the current fourth industrial revolution era.

\section{References}

Akerlof, R. (2006). A theory of social motivation. Unpublished Manuscript, Cambridge MA. https://www.academia. edu/181414/A_Theory_of_Social_Motivation

Alnıaçık, Ü., Alnıaçık, E., Akçin, K., \& Erat, S. (2012). Relationships Between Career Motivation, Affective Commitment and Job Satisfaction. Procedia - Social and Behavioral Sciences, 58, 355-362. https://doi.org/10.1016/j.sbspro.2012.09.1011

Andoko, C. Y., \& Sukhemi. (2015). The Influence of Motivation on the Interest of Accounting Students to Participate in Accounting Professional Education (PPAK). Akmenika: Jurnal Akuntansi Dan Manajemen, 12(2). http://ojs.upy.ac.id/ojs/index.php/akm/ article/view/121

Arifianto, F., \& Sukanti, S. (2014). The Influence of Self-Motivation and Perception of Public Accountant Profession on the Interest of Becoming Public Accountant in Accounting Students of Faculty of Economics, Yogyakarta State University. Nominal, Barometer Riset Akuntansi Dan Manajemen, 3(2), 150-161. https://doi.org/10.21831/nominal.v3i2.2700

Aryani, N. P. D., \& Erawati, N. M. A. (2016). The Influence of Motivation on Quality, Career, Economics, and Cost of Education on Student Interest in Following the Accounting Professional Education. E-Jurnal Akuntansi, 16(1), 362-384. https://ojs.unud.ac.id/index.php/Akuntansi/article/view/17469 
Benny, E., \& Yuskar. (2006). The Influence of Motivation on the Interest of Accounting Students in Following the Accounting Professional Education. Simposium Nasioanal Akuntansi IX, 1(1), 59-67. http://pdeb.fe.ui.ac.id/?p=7692

Berlinasari, M., \& Erawati, N. M. A. (2017). The Influence of Motivation, Education Costs and Long Education on Accounting Students Interests in Following PPAk. E-Jurnal Akuntansi, 21(1), 447-476. https://ojs.unud.ac.id/index.php/ Akuntansi/article/view/29588

Buss, D. M. (1997). Human Social Motivation in Evolutionary Perspective: Grounding Terror Management Theory. Psychological Inquiry, 8(1), 22-26. https://doi.org/10.1207/ s15327965pli0801_3

Condrorini, G. (2015). The Influence of Motivation on the Interest of Accounting Students to Participate in Accounting Professional Education (Case Study of Accounting Students at Dian Nuswantoro University and Stikubank University Semarang). In: Skripsi. Universitas Dian Nuswantoro.

Dewi, I. F., \& Setiawanta, Y. (2014). The Influence of Perceptions and Motivation of Accounting Department Students Who Are Taking Thesis on Career Interest in Taxation. Jurnal Akuntansi Fakultas Ekonomi Dan Bisnis Universitas Dian Nuswantoro Semarang. http://eprints.dinus.ac.id/8698/1/ jurnal_13222.pdf

Dyastari, N. P. S., \& Yadnyana, I. K. (2016). The Influence of Motivation on the Interest of Non-Accounting Students to Participate in Accounting Professional Education. E-Jurnal Akuntansi, 16(1), 333-361. https://ojs.unud.ac.id/index.php/ Akuntansi/article/view/17380

Garcia, P. R. J. M., Restubog, S. L. D., Bordia, P., Bordia, S., \& Roxas, R. E. O. (2015). Career optimism: The roles of contextual support and career decision-making self-efficacy. Journal of Vocational Behavior, 88, 10-18. https://doi. org/10.1016/j.jvb.2015.02.004

Goetsch, D. L., \& Davis, S. B. (2002). Introduction to Total Quality: Quality Management for Production, Processing, and Services (2nd ed.). Upper Saddle River, NJ: Prentice Hall.

Hadiprasetyo, T. (2014). The Influence of Motivation, Perception of Education Costs and Perception of Study Period on the Interest of Accounting Study Program Students. Jurnal Profita, 2(7). https://doi.org/10.1016/j.gaitpost.2018.03.005

Hauff, J. C., \& Nilsson, J. (2020). The influence of gender on the choice of education: The mediating effect of interest in statistics. Journal of International Education in Business, 13(1), 87-105. https://doi.org/10.1108/JIEB-07-2019-0032

Heizer, J., \& Render, B. (2004). Operations management (7th ed.). Upper Saddle River, NJ: Pearson Prentice Hall.

Kermis, G., \& Kermis, M. (2010). Professional Presence and Soft Skills: ARole for Accounting Education. Journal of Instructional Pedagogies, 2(3), 1-10. https://eric.ed.gov/?id=EJ1056346

Kusumastuti, R., \& Waluyo, I. (2013). The Influence of Motivation and Knowledge of Law No.5 of 2011 Concerning Public
Accountants on The Interest of Accounting Students Following Accounting Profession Education. Nominal, Barometer Riset Akuntansi Dan Manajemen, 2(2), 1-30. https://doi. org/10.21831/nominal.v2i2.1662

McClelland, D. (1961). The Achieving Society. New York, NY: Simon \& Schuster.

Le, H. Q. (2020). Factors affecting students' decision to select private universities in Vietnam. Journal of Asian Finance, Economics and Business, 7(4), 235-245. https://doi. org/10.13106/jafeb.2020.vol7.no4.235

Linasari, R. N., \& Fitriany, F. (2008). Factors affecting the interest of accounting students to take accounting profession education. In: The 2nd Accounting Conference, 1st Doctoral Colloquium, and Accounting Workshop.

Lunenburg, F. C. (2015). Expectancy Theory of Motivation: Motivating by Altering Expectations. International Journal of Management, Business, and Administration, 15(1), 1-6.

Martameh. (2012). Social Motivation. Universitas Gadjah Mada, Yogyakarta, Indonesia.

McClintock, C. G. (1972). Social motivation — a set of propositions. Behavioral Science, 17(5), 438-454. https://doi.org/10.1002/ bs.3830170505

Nurhayani, U. (2012). The influence of motivation on the interest of accounting students to take accounting profession education (Empirical study at private universities in Medan). Jurnal Mediasi, 4(1), 59-67.

Owusu, G. M. Y., Bekoe, R. A., Okyere, S. A., \& Welbeck, E. E. (2019). What influences the course major decision of accounting and non-accounting students? Journal of International Education in Business, 12(1), 26-42. https://doi.org/10.1108/ JIEB-02-2018-0004

Paais, M., \& Pattiruhu, J. R. (2020). Effect of motivation, leadership, and organizational culture on satisfaction and employee performance. Journal of Asian Finance, Economics and Business, 7(8), 577-588. https://doi.org/10.13106/jafeb.2020. vol7.no8.577

Pancasila, I., Haryono, S., \& Sulistyo, B. A. (2020). Effects of work motivation and leadership toward work satisfaction and employee performance: Evidence from Indonesia. Journal of Asian Finance, Economics and Business, 7(6), 387-397. https://doi.org/10.13106/jafeb.2020.vol7.no6.387

Robbins, S. P. (2008). Organizational Behavior. Jakarta, Indonesia: Salemba Empat. http://library.um.ac.id

Ryan, R. M., \& Powelson, C. L. (1991). Autonomy and relatedness as fundamental to motivation and education. Journal of Experimental Education, 60(1), 49-66. https://doi.org/10.108 0/00220973.1991.10806579

Schiffman, L., \& Kanuk, L. (2009). Consumer Behavior (10th ed.). Upper Saddle River, NJ: Prentice Hall.

Schindler, L., Puls-Elvidge, S., Welzant, H., \& Crawford, L. (2015). Definitions of quality in higher education: A synthesis of the 
literature. Higher Learning Research Communications, 5(3), 3-13. https://doi.org/10.18870/hlrc.v5i3.244

Setyaningsih, P. (2016). The Influence of Motivation, Tuition Fees, and Length of Education on the Interest of Accounting Students to Participate in Accounting Professional Education (PPAk) (Case Study of Accounting Students at Muhammadiyah University of Surakarta). In: Skripsi.

Shatskaya, I. V. (2019). Factors determining professional choices of students in educational institutions. Espacios, 40(26), 10-14.

Vansteenkiste, M., Sierens, E., Soenens, B., Luyckx, K., \& Lens, W. (2009). Motivational Profiles From a Self-Determination Perspective: The Quality of Motivation Matters. Journal of Educational Psychology, 101(3), 671-688. https://doi. org/10.1037/a0015083
Vesperalis, A. A. A. D., \& Muliartha, K. (2017). The Influence of Motivation on Accounting Bachelor Interest of Udayana University to Follow PPAk. E-Jurnal Akuntansi, 19(2), 1691-1718. https://ojs.unud.ac.id/index.php/Akuntansi/article/ view/30046

Widyastuti, S. W., Suryaningsum, S., \& Juliana, K. (2004). The Influence of Motivation on the Interest of Accounting Students to Participate in Accounting Professional Education (PPAK). In: Simposium Nasional Akuntansi VII. http://pdeb.fe.ui. ac.id/? $\mathrm{p}=6975$

Zyl, C., \& Villiers, C. (2011). Why some students choose to become chartered accountants (and others do not). Meditari Accountancy Research, 19(1/2), 56-74. https://doi. org/10.1108/10222521111178637 